\title{
Impacts of higher tobacco tax on output and employment in Vietnam
}

\author{
Hien Thu Thi Nguyen \\ Thuong Mai University, Hanoi, Vietnam \\ Long Thanh Giang \\ National Economics University, Hanoi, Vietnam and \\ IPAG Business School, Paris, France, and \\ Toan Ngoc Pham \\ Institute of Labour Science and Social Affairs, Hanoi, Vietnam
}

\begin{abstract}
Purpose - The purpose of this study was to evaluate how higher tax on tobacco would influence output and employment in Vietnam.

Design/methodology/approach - The authors used micro-simulation techniques proposed by Walbeeck (2010). Both national data (from Input-Output Table) and household data (Vietnam Household Living Standard Survey) were utilized.

Findings - The results showed that any increase in the excise tax for tobacco would have positive net impacts on both national output and employment. The tobacco industry would not be significantly affected due to its small contribution to national economy and employment. More importantly, money released from reduced tobacco consumption would be reallocated to other goods and services, and thus outputs and jobs in nontobacco sectors would increase.

Research limitations/implications - The key limitation of this study was due to unavailability of updated data, especially Input-Output Table as well as household living standard survey.

Practical implications - This study concluded that government should increase tax on cigarette along with a well-planned roadmap to avoid unexpected consequences on income and employment of laborers in this sector. Originality/value - This study replicated a popular approach in order to verify an important government policy (i.e. effect of tax on tobacco on output and employment) under Vietnamese context.
\end{abstract}

Keywords Employmen, Output, Tax policy, Tobacco control, Vietnam

Paper type Research paper

\section{Introduction}

Among industries in the manufacturing sector, tobacco production in Vietnam has a remarkable growth. According to the statistics from General Statistics Office for the period 1995-2011, the average growth rate of tobacco production - measured by the number of packs produced - was about $8 \%$ per annum. In particular, the number of packs produced increased from $2.15 \mathrm{~m}$ in 1995 to $4.84 \mathrm{~m}$ in 2005 and to $5.45 \mathrm{~m}$ in 2011. Vietnam Tobacco Association (VTA, 2013) showed that the number of packs produced in 2012 was slightly

(C) Hien Thu Thi Nguyen, Long Thanh Giang and Toan Ngoc Pham. Published in Journal of Economics and Development. Published by Emerald Publishing Limited. This article is published under the Creative Commons Attribution (CC BY 4.0) license. Anyone may reproduce, distribute, translate and create derivative works of this article (for both commercial and non-commercial purposes), subject to full attribution to the original publication and authors. The full terms of this license may be seen at http:// creativecommons.org/licences/by/4.0/legalcode

We are grateful to Dr. Pham Hoang Anh and Mrs. Le Thi Thu (HealthBridge) and Dr. Nguyen Tuan Lam (WHO Vietnam) for their insightful comments and suggestions on various drafts of this research. We would like to thank staff of HealthBridge Vietnam for collaborating different work related to this research.

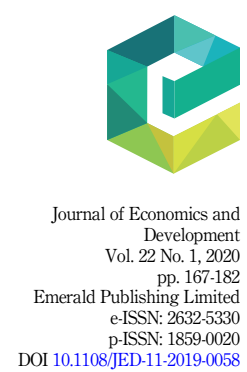


JED

22,1

168

higher than that in 2011 , at $5.6 \mathrm{~m}$. By market share, $80 \%$ of cigarettes produced were consumed domestically, while the remaining $20 \%$ were exported. In terms of economic contribution, VTA (2013) indicated that all tobacco producers contributed 14,908bn Vietnam Dong (VND) to the government budget, and about VND $877 b n$ as imported tax revenue. Revenue at current price for tobacco production increased from VND 16,477bn in 2005 to VND 27,372bn in 2010. Similarly, the total number of the employed in tobacco production decreased in recent years, from 537,220 persons in 2011 to 420,000 persons in 2012. The number of people working in the wholesale for tobacco decreased from 21,107 persons to 16,203 persons, and the same trend occurred with the retail from 139,190 persons to 128,064 persons.

As argued in various reports and discussions, however, tobacco use is one of the most preventable causes leading to fatal diseases and death in the world. Tobacco use caused over five million deaths each year and expected to cause over eight million deaths yearly by 2030 (Mathers and Loncar, 2006). In Vietnam, a simulation model developed for Vietnam estimated that nearly 40,000 deaths were attributed to smoking in 2008, and a figure to set to rise above 50,000 deaths annually by 2023 (Levy et al., 2006). An estimate from the Vietnam Household Living Standard Survey (VHLSS) in 2008 showed that the use of tobacco also imposed a burden on households in Vietnam with VND 14,000bn, which accounted for 5\% to $10 \%$ of total household consumption expenditure. Results from the Global Adult Tobacco Survey (GATS) by MOH et al. (2010) also indicated that Vietnam was one among the 15 countries with the highest numbers of smokers.

Given such a fact, the Government of Vietnam has made commitments and implemented measures to control tobacco production and consumption since 2000. The Government Resolution No.12/2000/NQ-CP on "National Tobacco Control Policy 2000-2010" which is being implemented by a Committee headed by the Ministry of Health (MOH) and draw from most ministries and community organizations. In 2003, Vietnam signed the Framework Convention on Tobacco Control (FCTC) and ratified it on 2004. In 2006, Vietnam had applied a uniform Special Consumption Tax (SCT) level at 55\% on all kinds of cigarettes instead of levying two rates of 45 and $65 \%$ on different kinds of cigarettes as before. Since April 2009, the SCT for tobacco has increased to $65 \%$ of the wholesale prices[1]. In 2009, the Prime Minister issued the Decision No.1315/QĐ-TTg on Ratification of the Action Plan for the Implementation of the World Health Organization's (WHO) FCTC, in which "from now until 2010, develop a price and taxation road map for tobacco products with the aim to: increase taxation and prices of tobacco products; levy high tax on imported tobacco products; apply regulations on minimum price for tobacco products; and apply measures to reduce and strictly control product sales at duty free shops" (Term a, Section I.1). Despite the efforts of the government and relevant agencies in the tobacco control activities, Vietnam was still among the countries with the highest smoking rate in the world (Higashi et al., 2011). GATS 2010 showed that the prevalence of smoking among adult men was $47.4 \%$ and among adult women was $1.4 \%$.

It has been argued that taxes on cigarettes have not been raised at a significant level to control tobacco consumption. On average, taxes on cigarettes accounts for almost $45 \%$ of the cigarette's retail sale price, which is much lower than many other countries and is below the recent WHO's recommendation rate (70\%). Findings from Guindon et al. (2010) showed that real cigarette prices (or inflation-adjusted prices) of three types of brand (the most expensive, the most popular and the cheapest) consistently declined over the past decade. Therefore, cigarette has become more affordable for Vietnamese consumers over time. Vietnam's Tobacco Control Program has been working hard to intensify tobacco control activities. However, it is facing policy issues regarding employment since this sector has created a significant number of jobs. According to Ministry of Industry and Trade, 2012 (MOIT), there were about 13,000 permanent jobs in producing and retailing activities, and about 250,000 seasonal jobs in the tobacco industry. 
Thus, two opposite points of view exist. The first group (such as social policy-makers, tobacco controllers, health care organizations and even tobacco users) based on a rich international and regional experience argued that tobacco control measures should be reinforced to decrease tobacco consumption and its consequences and that the SCT on tobacco products should be increased in order to limit the access of youth and the poor to tobacco and that tobacco tax increase would provide positive impact on the government's tax revenue and would not have any negative impact on employment. The second one, from cigarette-producing companies, claimed that strong tobacco control measures with heavy tax would have negative impact on employment and substantially reduce the tax revenue contributed by the tobacco industry to the government budget. As such, the key questions are: (1) how large were the contributions made by the tobacco industry to the economy? and (2) how measures to control cigarette production and consumption would affect the country's output and employment?

Given such a research demand, this research provided an evaluation of tobacco control measures on employment in this industry. In particular, this study estimated the number of jobs created in the industry; the industry's revenue and its contribution to the economy; and analyzed effects of tobacco control measures on employment. To pursue these important questions, this study used data from Input-Output (IO) Table in 2007 along with data from the VHLSS in 2008. This study added important pieces of information for policy-makers in forming tax policies and tobacco control measures in Vietnam.

In the next section, we presented a review of findings from previous studies in other countries on the similar topics. We discussed methodology and data in Section 3, while the main findings were presented in Section 4. The last Section concluded the research.

\section{Literature review}

In this section, we provided a review of previous studies on various Asian countries in order to see how tobacco tax increase would influence employment. Using data in the period 1980 1997, Hu and Mao (2002) estimated how number of jobs would have been changed if special consumption tax on tobacco in China was increased. The results showed that with a $5.4 \%$ loss of sales in the cigarette industry, employment rates would drop by the same percent which is about 27,000 employees. The authors suggested that a short-term solution could be cross subsidy from additional tobacco taxation to tobacco farmers and the cigarette manufacturing industry, which might result in transition to other products in the long-term. Also on China, Hu et al. (2008) conducted various simulations with different price-elastic demand for tobacco and found that, if the tax was 1 Yuan per tobacco pack, the tax revenue for government would have increased by $64.9 \mathrm{bn}$ Yuan (or US $\$ 7.9 \mathrm{bn}$ ), saved $3.4 \mathrm{~m}$ people (thanked to not smoke anymore, or smoke less), reduced health expenses by $2.68 b n$ Yuan (or US $\$ 325 m$ ) and increased labor productivity by $9.92 b n$ Yuan (or US $\$ 1.2 b n$ ) for the whole Chinese economy. Given the same tax rate and employment was considered as a linear function of tobacco output, the authors showed that revenue for the tobacco industry would have reduced by $1.6 \%$, and thus the number of jobs would be reduced by 1,656 (with assumed price-elastic demand was -0.15 ) or 5,549 (with assumed price-elastic demand was -0.5). In comparison with other industries with a loss of 59,000 jobs due to merging, such a loss in the tobacco industry would be very small.

Given a research question of how to maximize cigarette excise tax revenues in Indonesia, Marks (2003) used the Indonesia Central Board of Statistics in 2000 and the 2002 National Socioeconomic Survey. The results showed that the direct impact of an increase in cigarette tax on employment of production workers in the cigarette sector would be a loss of 89,756 jobs, with 86,820 jobs lost in the hand-rolled kretek sector (sigaret kretek tangan (SKT)). In the short-run, the workers who lost jobs in the cigarette industry most likely would be either
Impact of
higher tobacco
tax in Vietnam 
JED

22,1

unemployed or would work in the informal sector. From the findings, the author suggested that the effective tax rate on producers of SKT would be $21.8 \%$, and for cigarette producers overall would be $36.6 \%$. Exploring further the Indonesian case, Ahsan and Wiyono (2007), using the National Labor Force Survey 2003, found that increasing cigarette tax to the economy in terms of employment would be positive: increasing by $100 \%$ would create new jobs in 60 sectors while generate job losses in only six sectors. In detail, the number of new jobs would increase by 281,135 (or $0.3 \%$ of employment), 140,567 and 84,340 for a 26-percent point (or $100 \%$ increase), 13-percent points (or $50 \%$ increase) or 8-percent point (or about $25 \%$ increase) when increasing the cigarette tax. The net impact for employment in the whole economy would be positive. From the findings, the authors recommended that government should increase the cigarette tax because it would create more output, income and employment, and that government should increase cigarette tax and then use some of the increased tax revenue to help labor with transition from tobacco sectors to other sectors in the economy.

Barber et al. (2008) showed that the tobacco industry in Indonesia has contributed less than $1 \%$ of the total labor force since 1970s. Using socioeconomic survey (Susenas) and Indonesian Family Life Survey, the authors simulated the impact of higher tax on tobacco. The results indicated that if the current tax rate was doubled, there would have been $0.3 \%$ of the total labor force as newly generated ones (or 281,135 new jobs). The authors explained that tobacco leave growing and production industries were not highly productive ones, which could provide significant number of jobs with high salary.

Beginning with an argument that job loss in the tobacco industry due to higher tax would be compensated by job creation in other industries, John et al. (2010) proved the case of India. In particular, they showed that money that would not be spent for tobacco (due to quitting smoke or smoking less, which results from higher tobacco price) would not disappear from the economy; rather, it would be used for consumption in other goods and services, which in turn promote production on nontobacco industries. In addition, higher tax on tobacco in India would have positive impacts: an increase to 98 Rps for every 1,000 cigarettes produced would increase tax revenue by $36.9 \mathrm{bn}$ Rps, avoid $15.5 \mathrm{~m}$ death of young people among those who are smokers or will be smokers. Similarly, an increase to 369 Rps for every 1,000 cigarettes produced would increase tax revenue by $146.3 \mathrm{bn}$ Rps, avoid $3.4 \mathrm{~m}$ death of young people.

A study by Barkat et al. (2012) for Bangladesh indicated that employment in tobacco farming accounts for less than $0.5 \%$ of agricultural employment in Bangladesh. Using annual time series data on aggregate cigarette consumption from 1981 through 2004 to estimate price elasticity of demand for tobacco when higher tax is applied, the authors showed that taxing all cigarette brands at a specific tax rate of 34 taka per 10 sticks ( $70 \%$ of retail price) could lead nearly seven million current smokers to quit and prevent seven million youth from initiating smoking, preventing six million premature deaths and raising additional excise revenues of $15.1 \mathrm{bn}$ taka (US\$200m). Further, taxing all bidis at a specific tax rate of 4.95 taka per pack ( $40 \%$ of average prices) could lead $3.4 \mathrm{~m}$ adult bidi smokers to quit and prevent $3.5 \mathrm{~m}$ youth from initiating bidi smoking, preventing $2.5 \mathrm{~m}$ premature deaths and raising additional excise revenues of $7.2 b n$ taka (US\$ 87.5m).

In summary, raising tax on tobacco would have negative or positive impacts will depend on socioeconomic context of each country. Previous studies have indicated two conclusions as follows. First, if the tobacco industry accounts for a small proportion of the economy's output and has weak forward and backward linkages with other industries, higher tax on tobacco would reduce demand for tobacco, promote other industries due to higher demand of other goods which substitute for tobacco, and therefore promote investment and job creation. Second, if the tobacco industry accounts for a large proportion in the economy's output, higher tax on tobacco would have impacts on both short-term (the magnitude would depend 
on price-elasticity of demand for tobacco) and thus long-term employment of the tobacco industry in particular and the whole economy in general. Therefore, government's policies supporting firms and laborers would be crucial.

\section{Data and methodology}

\subsection{Data}

The main data used in this research were I-O Table, which could provide a comprehensive picture of an economy in aspects of production technology applied to create products, shown by input coefficients, use of output produced domestically (reflected by the structure of gross capital formation, final consumption and exports) and production income (described by the structure of compensation of employees, consumption of fixed capital, other net taxes on production and operating surplus). For this research, we used two I-O Tables in 2007. In addition, we also used VHLSS 2008 in order to have similar time frame for data with I-O Table 2007. The VHLSS could provide rich information on household consumption on various goods and services, including tobacco products.

Along with I-O Table 2007 and VHLSS 2008, to make estimates for other indicators, we also used various sources of data at the national level. Table 1 presents the studied indicators and their respective sources.

\subsection{Methodology}

3.2.1 Estimation framework, estimation steps and assumptions. Figure 1 presents framework for our estimation of the impacts of tax on cigarette on employment. To follow the above framework, we conducted the following estimation steps:

(1) Using estimation model proposed by Walbeeck (2010), we estimated the reduction in smoking rate. Then, we transferred the reduction in smoking rate to reduction in household expenditure of cigarette due to higher excise tax on tobacco.

(2) Based on the household consumption model, which was estimated from the household survey, we examined how households would have switched from cigarette consumption to other consumptions when tax on cigarette had been increased.

(3) We used I-O analysis method to estimate the impact of higher tax on tobacco on the national output and employment. In particular, we examined two different policy scenarios of tax on tobacco and their potential impacts on national output and employment.
Impact of higher tobacco tax in Vietnam $\begin{array}{lll}\text { No Indicators } & \text { Source(s) }\end{array}$

1 Number of hectares tobacco cultivated

2 Number of working hours required per 1 ha of tobacco cultivating

3 Average retail price and whole sale price with tax of $\quad$ MOF (2013) cigarette

4 Cigarette retail sale

$5 \quad$ GDP in whole distribution sector

$6 \quad$ Number of labor in whole country and sectors

7 Smoking rate

Source(s): Own combinations from various sources
Statistical Yearbooks (GSO)

Nguyen et al. (2008)

Vietnam Tobacco Association (VTA) Annual Report

Statistical Yearbook (GSO)

Employment and Labor Force Surveys (GSO)

Global Adult Tobacco Survey (GATS) (2010)
Table 1.

Studied indicators and their sources 


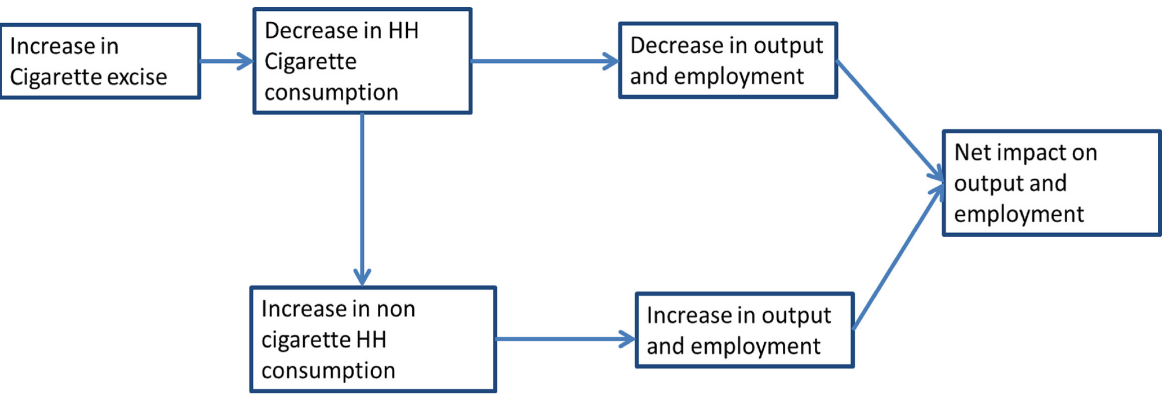

Figure 1.

Estimation framework

Source(s): Adapted from Walbeeck (2010)

To pursue the estimation steps above, especially in applying I-O analysis method with some explicit limitation[2], we have following assumptions: (1) no change in government expenditure; (2) no change in production technology and (3) the laborers could easily move from tobacco-related sectors to other sectors when they became unemployed.

3.2.2 Estimate employment in the tobacco industry.

(1) Tobacco farming employment

First, estimate the total amount of working hours used in tobacco production:

Total working hours $=$ number of working hours required per 1 hectare of tobacco per crop $*$ number of ha of tobacco planted $* 2$ crops

Then, we converted the calculated working hours into the equivalent number of full-time employments:

Number of full - time labors $=$ total working hours $\div$ standard working hours of a full

$$
\text { - time labors }
$$

(2) Leaf marketing and processing employment

In Vietnam, after farmers did one part of the processing (raw-drying), they sold their semiprocessed tobacco products to tobacco material processed manufacturers and other tobacco manufacture enterprises. The major of employment created by this sector was included in the manufacturing sector, and thus we could not estimate the employment in this sector separately.

(3) Tobacco manufacturing employment

These data were obtained from the official statistics (such as Enterprise Census and Labor Force Survey, Annual VTA Reports). In this study, the data were from the Labor Force Survey in 2010.

(4) Tobacco distribution sector employment

We used indirect method to estimate the employment in this sector based on the value added (gross domestic product (GDP)) from tobacco distribution sector as follows: to calculate the retail margin in the distribution sector, we first calculated the retail margin per pack of cigarette, which was equal to the average retail price of cigarette minus the average wholesale 
price with tax. Ministry of Finance (MOF, 2013) calculated the average retail price of cigarette in 2010 was 7,931 VND per pack and the whole sale price with tax per pack was VND 7,210. So the retain margin per pack in distribution sector was VND $721(=7921-7210)$. The total sales of cigarette was multiplied by the retail margin per pack equaled the GDP created in the cigarette distribution sector $\left(G D P_{\text {dist. tob }}\right)$. Then, total employment created by the cigarette distribution could be calculated as follows:

$$
\begin{aligned}
& \text { Number of jobs created by cigarette distribution } \\
& =\left(\mathrm{GDP}_{\text {dist.tob }} / \mathrm{GDP} \text { of the whole distribution sector }\right) \\
& \quad * \text { number of jobs in the whole distribution sector }
\end{aligned}
$$

3.2.3 Estimate the share of tobacco sector's employment in the national employment. We calculated the ratio of employment to total employment in three separate sectors that the tobacco industry belonged to and the ratio of employment of the tobacco industry to total national employment. We had four measurements: (1) The percent of jobs associated with tobacco farming to total employment for agriculture production; (2) The percent of jobs associated with tobacco manufacturing to total employment in manufacturing; (3) The percent of jobs associated with tobacco wholesaling and retailing to total employment in wholesaling and retailing and (4) The percent of tobacco jobs to total national employment.

\section{Findings and discussions}

\subsection{Impacts of tobacco tax on households' final consumption}

Luong (2014) showed that a 20 percent point increase in excise tax of tobacco (from current $65 \%$ to proposed $85 \%$ ) would reduce smoking rate from $23.8 \%$ to $23.2 \%$ (or a $2.52 \%$ reduction); while with 40 percent point increase in the excise tax of tobacco (from current $65 \%$ to proposed $105 \%$ ), the smoking rate would reduce from $23.8 \%$ to $22.6 \%$ (or a $5.04 \%$ reduction). Using these results, we calculated how much cigarette consumption (in VND) would reduce under the two scenarios, i.e. a $20 \%$ tobacco excise tax increase (from $65 \%$ to $85 \%$ ), and a $40 \%$ tobacco excise tax increase (from $65 \%$ to $105 \%$ ). The total expenditure of household on cigarette in year 2007 was about VND 11,100 bn. Annual increase in tobacco consumption was estimated by increase in the number of consumed tobacco packs multiplied by inflation rate (estimated from consumer's price index). According to VTA, the number of consumed tobacco packs increased from $3,571 \mathrm{~m}$ in 2008 to $4,068.5 \mathrm{~m}$ in 2012. Therefore, annual growth rate of the consumed tobacco packs was $4.23 \%\left(=(4068.5 / 3571-1)^{*} 100 / 4\right)$. Inflation rate was $23 \%$ in 2008 ; $6.9 \%$ in 2009 and $9.2 \%$ in 2010 . Thus, total household consumption on tobacco was VND $17,802 b n$ in 2010.

For the first scenario, we transfer a $2.52 \%$ reduction in smoking prevalence to decreased level in cigarette consumption of households. The total expenditure of household on cigarette in year 2010 was VND 17,802bn, so the total value of cigarette consumption of household was VND 17,802bn with the smoking prevalence at $23.8 \%$. Smoking prevalence after $20 \%$ increase in tax of tobacco was $23.2 \%$. We assumed that the reduction in smoking prevalence would lead to decrease in cigarette consumption correspondingly. Therefore, a $2.52 \%$ reduction in smoking prevalence would lead to VND $449.8 b n(=17,802 \times 2.52 \%)$ decrease in household expenditure on cigarettes. But increasing tax would also lead to increasing in the price of cigarette and thus would reduce smoking intensity among continuing smokers. In this study, we assumed that half of the impact of increasing tax was on prevalence and half on the consumption among 
JED

22,1

174

continuing smokers, and thus the total decline in cigarette consumption would be twice and equal to VND 897.56bn. $(=2 * 449.8)[3]$.

For the second scenario, we did the same steps to the basic scenario: $40 \%$ increase in tax of tobacco would lead to decrease in household consumption of cigarette by VND 1,795.11bn. The amount of money saved from reducing tobacco consumption could be used for consumption on other goods and services, as well as savings. However, due to lack of data on such behaviors, we assumed that households would use $50 \%$ of saved money for consumption on other goods and services. To estimate the impact of switching from consumption of cigarette to consumption in other sectors, we allocated this reduction of cigarette expenditure to other "non-manufacture of cigarette" sectors of household expenditure. Such allocation was based on the ratio of the household expenditure to other nonmanufacture of cigarette that was calculated from household expenditure in the $\mathrm{I}-\mathrm{O}$ Table in 2007. The results are presented in Table 2.

\begin{tabular}{|c|c|c|c|c|}
\hline \multirow[b]{2}{*}{ Sector } & \multirow[b]{2}{*}{$\begin{array}{c}\text { Household } \\
\text { consumption } \\
\text { (VND millions) }\end{array}$} & \multirow[b]{2}{*}{ Ratio } & \multicolumn{2}{|c|}{$\begin{array}{l}\text { Allocation of consumption to } \\
\text { other sectors due to reduced } \\
\text { consumption on tobacco } \\
\text { (VND billion) }\end{array}$} \\
\hline & & & $\begin{array}{l}\text { 20-percent } \\
\text { point tax } \\
\text { increase }\end{array}$ & $\begin{array}{l}\text { 40-percent } \\
\text { point tax } \\
\text { increase }\end{array}$ \\
\hline Agriculture, forestry and fishing & $50,487,605$ & $7.51 \%$ & 33.7 & 67.4 \\
\hline Mining and quarrying & $3,052,818$ & $0.37 \%$ & 1.7 & 3.3 \\
\hline Manufacturing & $408,683,366$ & $49.87 \%$ & 223.8 & 447.6 \\
\hline Tobacco manufacture & $11,099,650$ & $0.00 \%$ & 0.0 & 0.0 \\
\hline $\begin{array}{l}\text { Electricity, gas, steam and air conditioning } \\
\text { supply }\end{array}$ & $25,161,841$ & $3.07 \%$ & 13.8 & 27.6 \\
\hline $\begin{array}{l}\text { Water supply; sewerage, waste } \\
\text { management and remediation activities }\end{array}$ & $12,126,026$ & $1.48 \%$ & 6.6 & 13.3 \\
\hline Construction & $(0)$ & $0.00 \%$ & 0.0 & 0.0 \\
\hline $\begin{array}{l}\text { Wholesale and retail trade; repair of motor } \\
\text { vehicles and motorcycles }\end{array}$ & $23,451,763$ & $2.86 \%$ & 12.8 & 25.7 \\
\hline Transportation and storage & $36,847,023$ & $4.50 \%$ & 20.2 & 40.4 \\
\hline Accommodation and food service activities & $47,188,804$ & $5.76 \%$ & 25.8 & 51.7 \\
\hline Information and communication & $31,772,229$ & $3.88 \%$ & 17.4 & 34.8 \\
\hline Financial and insurance activities & $22,756,554$ & $2.78 \%$ & 12.5 & 24.9 \\
\hline Real estate activities & $33,884,693$ & $4.13 \%$ & 18.6 & 37.1 \\
\hline $\begin{array}{l}\text { Professional, scientific and technical } \\
\text { activities }\end{array}$ & $5,134,437$ & $0.63 \%$ & 2.8 & 5.6 \\
\hline $\begin{array}{l}\text { Administrative and support service } \\
\text { activities }\end{array}$ & $6,668,274$ & $0.81 \%$ & 3.7 & 7.3 \\
\hline Public administration and defense & $7,146,370$ & $0.87 \%$ & 3.9 & 7.8 \\
\hline Education & $47,487,299$ & $5.79 \%$ & 26.0 & 52.0 \\
\hline Human health and social work activities & $37,000,900$ & $4.52 \%$ & 20.3 & 40.5 \\
\hline Arts, entertainment and recreation & $4,821,563$ & $0.59 \%$ & 2.6 & 5.3 \\
\hline Other service activities & 1,903 & $0.00 \%$ & 0.0 & 0.0 \\
\hline $\begin{array}{l}\text { Activities of households as employers; } \\
\text { undifferentiated goods- and services- } \\
\text { producing activities of households for own } \\
\text { use }\end{array}$ & $3,865,609$ & $0.47 \%$ & 2.1 & 4.2 \\
\hline $\begin{array}{l}\text { Activities of extraterritorial organizations } \\
\text { and bodies }\end{array}$ & 844,549 & $0.10 \%$ & 0.5 & 0.9 \\
\hline Total & $819,483,275$ & $100 \%$ & 448.8 & 897.6 \\
\hline
\end{tabular}

Table 2.

Change in household' final consumption of goods and services due to 20-percent point and 40-percent point increase in excise tax on tobacco

Source(s): Own calculations, using I-O Table 2007 
Through output and employment multiplier, we could calculate the impact of decreasing cigarette consumption to output and employment for the whole economy and the net impact of increase tax on tobacco in terms of output and employment.

\subsection{Contribution of tobacco industry to employment}

In this part, we presented some estimated results on the share of employment created by the tobacco industry for the economy. We also presented the share of employment created by the tobacco cultivation sector, cigarette production sector, cigarette distribution sector and the entire tobacco industry.

4.2.1 Contribution of tobacco cultivation sector. In this study, we estimated the employment created by the tobacco cultivation sector using data of hours requires to cultivating 1 hectare (ha) of tobacco and number of hectares of tobacco cultivated in Vietnam. From the survey, Nguyen et al. (2008) found that the time needed for to cultivate 1 ha of tobacco (two crops per annum) was about 7,000-10,000 person-hours, which was equivalent 3.5-5 full-time employees. Vinataba (2014) also provided a similar number of hours to cultivate 1 ha of tobacco, in which it needed 500 working hours to cultivate a hectare per crop. Therefore, we assumed that cultivation of 1 ha of tobacco would create four full-time jobs and this number would be constant due to the assumption that technology would be unchanged. Then, the number of employment created by the tobacco cultivation was upon on tobacco cultivation area. Table 3 shows the number of tobacco cultivation areas; employment created by tobacco cultivation sector and the share of tobacco cultivation sector labor in the whole agricultural labor force. Because we did not have data of the planted area in the year 2010, we assumed that the planted area in this year was the same that in the year 2009.

4.2.2 Contribution of tobacco manufacture sector. The share of labor in the cigarette production sector among the entire industry was presented in Table 4. In 2010, labor created by this sector presented $0.044 \%$ of the total labor force in the entire manufacturing industry.

4.2.3 Contribution of tobacco distribution sector. Using the total tax revenues and volume of retail sales along with an assumption that the retail margin per pact was $20 \%$, we calculated the GDP created by the cigarette distribution sector. From the GDP created by the

\begin{tabular}{ccccc}
\hline Year & $\begin{array}{c}\text { Planted } \\
\text { area(hectares) }\end{array}$ & $\begin{array}{c}\text { Full time } \\
\text { employment } \\
\text { (own estimation) }\end{array}$ & $\begin{array}{c}\text { Share of whole agriculture } \\
\text { sector }(\%)\end{array}$ & $\begin{array}{c}\text { Share of whole } \\
\text { economy }(\%)\end{array}$ \\
\hline 2005 & 16,800 & 62,160 & 0.26 & 0.15 \\
2006 & 26,700 & 98,790 & 0.41 & 0.22 \\
2007 & 19,200 & 71,040 & 0.29 & 0.16 \\
2008 & 16,400 & 60,680 & 0.25 & 0.13 \\
2009 & 20,300 & 75,110 & 0.31 & 0.16 \\
2010 & 26,161 & 96,796 & 0.40 & 0.20
\end{tabular}

Source(s): GSO (2010) and own estimations

\begin{tabular}{lccc}
\hline Year & $\begin{array}{c}\text { Labor in tobacco manufacture } \\
\text { sector }^{1}\end{array}$ & $\begin{array}{c}\text { Share of total labor in the industrial } \\
(\%)^{2}\end{array}$ & $\begin{array}{c}\text { Share of whole economy } \\
(\%)^{3}\end{array}$ \\
\hline 2005 & 18,400 & 0.33 & 0.043 \\
2006 & 17,991 & 0.32 & 0.041 \\
2010 & 13,908 & 0.21 & 0.028
\end{tabular}

Source(s): [1] VTA Annual Report; [2, 3] own estimates using data from various GSO statistical yearbooks
Impact of higher tobacco tax in Vietnam

\section{tax in Vietnam}

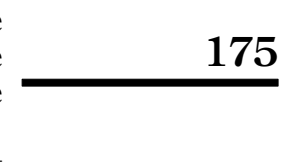


cigarette distribution sector, we could estimate the employment that the sector creates. The results were presented in Table 5. In 2010, total employment (full-time retailers) created by this sector was about 43.05 thousands, accounting for $3.7 \%$ of the total distribution sector. If we assumed that rate of return in distribution activities was $10 \%$, the number of jobs created by distribution sector would be 21,530 . Similarly, if the rate of return was assumed at $20 \%$, the number of jobs created by distribution sector would be 64,580 .

4.2.4 Contribution of tobacco industry to national employment. In this part, we estimated the contribution of the tobacco industry to the economy in year 2010. Total employment in all sectors of the economy in 2010 was 49,225,875 laborers. Table 6 shows the number and share of employment in each sector in the economy. In 2010, employment in the tobacco industry accounted for $0.3 \%$ of the total nationwide. In which, the tobacco cultivation sector

\begin{tabular}{llr}
\hline Indicators & Unit & 2010 \\
\hline Total tax revenue & Bil. VND & 11,180 \\
Cigarette retail sale & Mil. Pack & 4,068 \\
Whole sale price with tax per pack & VND & 2,748 \\
Retail margin per pack (20\%) & VND & 550 \\
GDP in cig. distribution (retail margin 20\%) & Bill VND' & 2,236 \\
GDP in whole distribution sector & Bill VND' & 759,202 \\
Number of labors in whole distribution sector & Person & $1,461,700$ \\
Number of jobs created in cig. trade sector & Person & 43,050 \\
Source(s): Authors' estimates & &
\end{tabular}

Table 5

Number of employment created by the cigarette trade sector, Vietnam 2010
Source(s): Authors' estimates

\begin{tabular}{llrr}
\hline Code & Sector & No. of labor & Total \% \\
\hline 1 & Agriculture, forestry and fishing & $23,970,221$ & \multicolumn{1}{c}{48.69} \\
& In which: cigarette plant cultivation & 277,952 & \multicolumn{1}{c}{0.2} \\
2 & Mining and quarrying & $7,057,385$ & 14.34 \\
3 & Manufacturing & 13,908 & 0.03 \\
4 & Tobacco manufacture & 135,284 & 0.27 \\
5 & Electricity, gas, steam and air conditioning supply & 118,426 & 0.24 \\
6 & Water supply; sewerage, waste management and remediation activities & $3,183,592$ & 6.26 \\
7 & Construction & $5,671,717$ & 11.52 \\
8 & Wholesale and retail trade; repair of motor vehicles and motorcycles & & 0.09 \\
& In which: cigarette distribution sector & $1,428,602$ & 2.90 \\
10 & Transportation and storage & $1,826,152$ & 3.71 \\
11 & Accommodation and food service activities & 259,554 & 0.53 \\
12 & Information and communication & 256,600 & 0.52 \\
13 & Financial and insurance activities & 149,146 & 0.21 \\
14 & Real estate activities & 219,323 & 0.45 \\
15 & Professional, scientific and technical activities & 187,028 & 0.38 \\
16 & Administrative and support service activities & $1,366,502$ & 2.78 \\
17 & Public administration and defense & $1,687,408$ & 3.43 \\
18 & Education & 441,646 & 0.90 \\
19 & Human health and social work activities & 234,345 & 0.48 \\
20 & Arts, entertainment and recreation & 696,028 & 1.41 \\
21 & Other service activities & 198,308 & 0.40 \\
22 & Activities of households as employers; undifferentiated goods- and & & \\
& services-producing activities of households for own use & 2,559 & 0.01 \\
23 & Activities of extraterritorial organizations and bodies & $49,382,000$ & 100 \\
& Total & &
\end{tabular}

Table 6.

Employment by

sectors, Vietnam, 2010

Source(s): ILO (2011) 
contributed $0.2 \%$ (or 96,976 jobs), tobacco manufacture contributed $0.028 \%$ (or 13,908 jobs), tobacco distribution sector contributed $0.09 \%$ (or 43,050 jobs) in the total jobs of the economy. This provided evidence that labor in the tobacco distribution and manufacture sector was really small in the total labor force.

\subsection{Contribution of the tobacco manufacture in national output}

Table 7 presented total output by sectors in Vietnam in the year 2010. The total output in 2010 was VND 2,861,116bn. The agriculture sector contributed $11.9 \%$; the industrial and construction sector presented $44,79 \%$ and $10,31 \%$, respectively and the services sector accounted for $27 \%$. The manufacture of cigarette and other tobacco products presented only $0.75 \%$. This sector was ranked 16th among 22 sectors in the economy in terms of gross output.

\subsection{Impacts of tobacco tax on national output and employment - simulated results for an} increase by 20 percent points (65\% to 85\%) and by 40 percent points (65\% to 105\%)

4.4.1 Impact on national output. The impact of changing cigarette expenditure on output under different policy scenarios was calculated with an assumption that final demand for tobacco product was reduced, and the released money from cigarette expenditure was allocated to other goods and services. The summary of output impacts was presented in Table 8.

4.4.2 Impact of 20-percent point increase in tax on tobacco. For the negative impact, 20percent point increase in tax of tobacco would lead to a reduction of cigarette consumption by

\begin{tabular}{|c|c|c|c|}
\hline Code & Sector & $\begin{array}{l}\text { Gross output } \\
\text { (VND billion) }\end{array}$ & $\begin{array}{l}\% \text { of total } \\
\text { output }\end{array}$ \\
\hline 1 & Agriculture, forestry and fishing & $340,573.96$ & 11.90 \\
\hline 2 & Mining and quarrying & $123,266.59$ & 4.31 \\
\hline $3 \mathrm{a}$ & Manufacturing & $1,281,459.45$ & 44.79 \\
\hline $3 \mathrm{~b}$ & Tobacco manufacture & $21,519.83$ & 0.75 \\
\hline 4 & Electricity, gas, steam and air conditioning supply & $71,982.89$ & 2.52 \\
\hline 5 & $\begin{array}{l}\text { Water supply; sewerage, waste management and remediation } \\
\text { activities }\end{array}$ & $7,284.15$ & 0.25 \\
\hline 6 & Construction & $295,027.98$ & 10.31 \\
\hline 7 & $\begin{array}{l}\text { Wholesale and retail trade; repair of motor vehicles and } \\
\text { motorcycles }\end{array}$ & $192,571.21$ & 6.73 \\
\hline 8 & Transportation and storage & $96,474.97$ & 3.37 \\
\hline 9 & Accommodation and food service activities & $63,152.51$ & 2.21 \\
\hline 10 & Information and communication & $66,906.79$ & 2.34 \\
\hline 11 & Financial and insurance activities & $35,746.60$ & 1.25 \\
\hline 12 & Real estate activities & $54,011.69$ & 1.89 \\
\hline 13 & Professional, scientific and technical activities & $26,056.18$ & 0.91 \\
\hline 14 & Administrative and support service activities & $11,440.28$ & 0.40 \\
\hline 15 & Public administration and defense & $58,337.64$ & 2.04 \\
\hline 16 & Education & $54,472.99$ & 1.90 \\
\hline 17 & Human health and social work activities & $44,701.45$ & 1.56 \\
\hline 18 & Arts, entertainment and recreation & $5,843.01$ & 0.20 \\
\hline 19 & Other service activities & $2,607.52$ & 0.09 \\
\hline 20 & Activities of households as employers & $4,900.87$ & 0.17 \\
\hline \multirow[t]{2}{*}{21} & Activities of extraterritorial organizations and bodies & $2,777.50$ & 0.10 \\
\hline & Total & $2,861,116.05$ & \\
\hline
\end{tabular}

Impact of higher tobacco tax in Vietnam

Source(s): Own estimates, using I-O Table 2007

Table 7.

Gross output by sector, Vietnam, 2010 
JED
22,1

\begin{tabular}{|c|c|c|c|c|c|c|c|}
\hline \multirow[b]{2}{*}{$\begin{array}{l}\text { I-O } \\
\text { code }\end{array}$} & \multirow[b]{2}{*}{ Sector } & \multicolumn{3}{|c|}{$\begin{array}{l}\text { 20-percent point increase in tax of } \\
\text { tobacco }\end{array}$} & \multicolumn{3}{|c|}{$\begin{array}{l}\text { 40-percent point increase in tax of } \\
\text { tobacco }\end{array}$} \\
\hline & & Decrease & Increase & $\begin{array}{c}\text { Net } \\
\text { impact }\end{array}$ & Decrease & Increase & $\begin{array}{c}\text { Net } \\
\text { impact }\end{array}$ \\
\hline 1 & $\begin{array}{l}\text { Agriculture, forestry and } \\
\text { fishing }\end{array}$ & -38.0 & 330.3 & 292.2 & -76.1 & 660.5 & 584.4 \\
\hline 2 & Mining and quarrying & -4.7 & 129.8 & 125.2 & -9.3 & 259.7 & 250.4 \\
\hline $3 a$ & Manufacturing & -20.6 & 606.6 & 586.1 & -41.1 & $1,213.3$ & $1,172.2$ \\
\hline $3 \mathrm{~b}$ & Tobacco manufacture & $-1,059.4$ & 2.1 & $-1,057.3$ & $-2,118.7$ & 4.2 & $-2,114.5$ \\
\hline 4 & $\begin{array}{l}\text { Electricity, gas, steam and } \\
\text { air conditioning supply }\end{array}$ & -11.1 & 238.4 & 227.3 & -22.2 & 476.8 & 454.6 \\
\hline 5 & $\begin{array}{l}\text { Water supply; sewerage, } \\
\text { waste management and } \\
\text { remediation activities }\end{array}$ & -17.5 & 276.4 & 258.9 & -35.0 & 552.8 & 517.8 \\
\hline 6 & Construction & -0.3 & 6.4 & 6.1 & -0.6 & 12.8 & 12.2 \\
\hline 7 & $\begin{array}{l}\text { Wholesale and retail trade; } \\
\text { repair of motor vehicles } \\
\text { and motorcycles }\end{array}$ & -18.0 & 274.9 & 256.8 & -36.1 & 549.7 & 513.7 \\
\hline 8 & $\begin{array}{l}\text { Transportation and } \\
\text { storage }\end{array}$ & -12.5 & 248.8 & 236.3 & -25.0 & 497.6 & 472.6 \\
\hline 9 & $\begin{array}{l}\text { Accommodation and food } \\
\text { service activities }\end{array}$ & -1.7 & 57.0 & 55.3 & -3.3 & 113.9 & 110.6 \\
\hline 10 & $\begin{array}{l}\text { Information and } \\
\text { communication }\end{array}$ & -5.5 & 126.9 & 121.4 & -10.9 & 253.8 & 242.8 \\
\hline 11 & $\begin{array}{l}\text { Financial and insurance } \\
\text { activities }\end{array}$ & -6.0 & 151.3 & 145.2 & -12.1 & 302.6 & 290.5 \\
\hline 12 & Real estate activities & -4.1 & 86.2 & 82.1 & -8.2 & 172.4 & 164.1 \\
\hline 13 & $\begin{array}{l}\text { Professional, scientific and } \\
\text { technical activities }\end{array}$ & -13.1 & 212.8 & 199.7 & -26.2 & 425.6 & 399.4 \\
\hline 14 & $\begin{array}{l}\text { Administrative and } \\
\text { support service activities }\end{array}$ & -7.7 & 120.3 & 112.6 & -15.5 & 240.7 & 225.2 \\
\hline 15 & $\begin{array}{l}\text { Public administration and } \\
\text { defense }\end{array}$ & 0.0 & 4.9 & 4.8 & -0.1 & 9.7 & 9.7 \\
\hline 16 & Education & -0.2 & 32.2 & 32.0 & -0.5 & 64.4 & 63.9 \\
\hline 17 & $\begin{array}{l}\text { Human health and social } \\
\text { work activities }\end{array}$ & -0.3 & 27.8 & 27.5 & -0.5 & 55.6 & 55.1 \\
\hline 18 & $\begin{array}{l}\text { Arts, entertainment and } \\
\text { recreation }\end{array}$ & -0.6 & 15.1 & 14.5 & -1.3 & 30.2 & 28.9 \\
\hline 19 & Other service activities & -1.6 & 41.6 & 40.0 & -3.3 & 83.2 & 79.9 \\
\hline 20 & $\begin{array}{l}\text { Activities of households as } \\
\text { employers }\end{array}$ & -1.9 & 40.7 & 38.8 & -3.9 & 81.4 & 77.6 \\
\hline 21 & $\begin{array}{l}\text { Activities of extraterritorial } \\
\text { organizations and bodies }\end{array}$ & -8.7 & 182.4 & 173.7 & -17.4 & 364.8 & 347.4 \\
\hline & Total & $-1,233.6$ & $3,212.9$ & $1,979.3$ & $-2,467.3$ & $6,425.8$ & $3,958.5$ \\
\hline
\end{tabular}

Impacts of tax changes on national output (VND billion)

Source(s): Own estimates, using I-O Table 2007

VND 897.56bn and a decrease in the total output by VND 1,233.6bn. For the positive impact, 20-percent point increase in tax of tobacco would lead to an increase in consumption on other goods and services by $50 \%$ amount of money released from reduction of tobacco expenditure (or VND 448.8bn), and an increase in the total output by VND 3,212.9bn. The total net impact on national output of 20-percent point increase in tax of tobacco, therefore, would be positive. The total outputs in the economy increases by $0.09 \%$ (or VND 1,979.3bn) from the initial total outputs (VND 2,157,828bn). 
4.4.3 Impact of 40-percent point increase in tax on tobacco. For the negative impact, 40percent point increase in tax of tobacco would lead to a reduction of cigarette consumption by VND 1,795.1bn, and a decrease in the total output by VND 2,467.3bn. For the positive impact, 40-percent point increase in tax of tobacco would lead to an increase in consumption on other goods and services by $50 \%$ amount of money released from reduction of tobacco expenditure (or VND 897.5bn), and an increase in the total output by VND 6,425.8bn. Total net impact on output of 40-percent point increase in tax of tobacco, therefore, would be also positive: in this optimistic scenario, the total national output would increase by $0.18 \%$ (or VND 3,958.5bn) from the initial total outputs (VND 2,157,828bn).

4.4.4 Impact on national employment. Table 9 presents the overall change in employment as a result of 20-percent point and 40-percent point increase in tax of tobacco. The year 2010 was also used as the base year for the estimation. The total employment of the whole country in 2010 was $49.38 m$

4.4.5 Impact of 20-percent point increase in tax on tobacco. For the negative impact, 20-percent point increase in tax of tobacco would lead to a reduction in cigarette consumption by VND $897.56 b n$, and a decrease in the total employment 5,386 jobs. For the positive impact, 20-percent point increase in tax of tobacco would result in an increase in the consumption of other goods and services by $50 \%$ amount of money released from reduction of tobacco expenditure (or VND 448.8bn), and an increase in the total employment by 65,664 jobs. Therefore, the total net impact on employment of 20-percent point increase in tax of tobacco would be positive. The total employment in the economy would increase by $0.12 \%$ (or 65,664 $5,386=60,278$ jobs) from the initial total number of jobs at $49.38 \mathrm{~m}$.

4.4.6 Impact of 40-percent point increase in tax on tobacco. For the negative impact, 40percent point increase in tax of tobacco would lead to a reduction on cigarette consumption by VND 1,795.1bn, and a decrease in the total national employment by 10,773 jobs. For the positive impact, 40-percent point increase in tax of tobacco would lead to an increase in consumption on other goods and services by $50 \%$ amount of money released from reduction of tobacco expenditure (or VND 897.5bn), and an increase in the total national employment by 131,328 jobs. The net impact on employment in the economy was also positive. The total national employment in the economy would increase by $0.24 \%$ (or $131,328-10,773=120,555$ jobs) from the initial total number of jobs at $49.38 \mathrm{~m}$.

\section{Concluding remarks}

Implementing tobacco control policies would lead to reduce smoking prevalence and have a positive implication for the whole economy: 20-percent point increase in tax of tobacco would increase the national output by $0.09 \%$ (or VND $1,979.3 \mathrm{bn}$ ) and employment by $0.12 \%$ (or 60,278 jobs); and 40-percent point increase in tax of tobacco would increase the national output by $0.18 \%$ (or VND 3,958.5bn) and employment by $0.24 \%$ (or 120,555 jobs). There would be 21 out of 22 sectors in the economy to have net positive gains from tobacco control policies in terms of output and employment. The only sector having net negative impact would be manufacture of cigarettes and other tobacco products.

The tobacco manufacturers have argued that tobacco control policies would reduce the output and employment in the economy because they assumed that the released cigarette expenditure would be simply disappeared from economy and thus the final demand for tobacco products would be fully eliminated, and there would be no increase in final demand for other alternative goods and services. This study, however, showed clearly that the reduction in final demand for tobacco products could result in increases in demand for other goods and services and help to create more jobs in these sectors. The net impact of tobacco control on employment, as discussed above, would be generally positive for the whole economy.
Impact of
higher tobacco
tax in Vietnam 
JED
22,1

180
Table 9.

Impacts of tax changes on national employment (unit: 1,000 jobs)

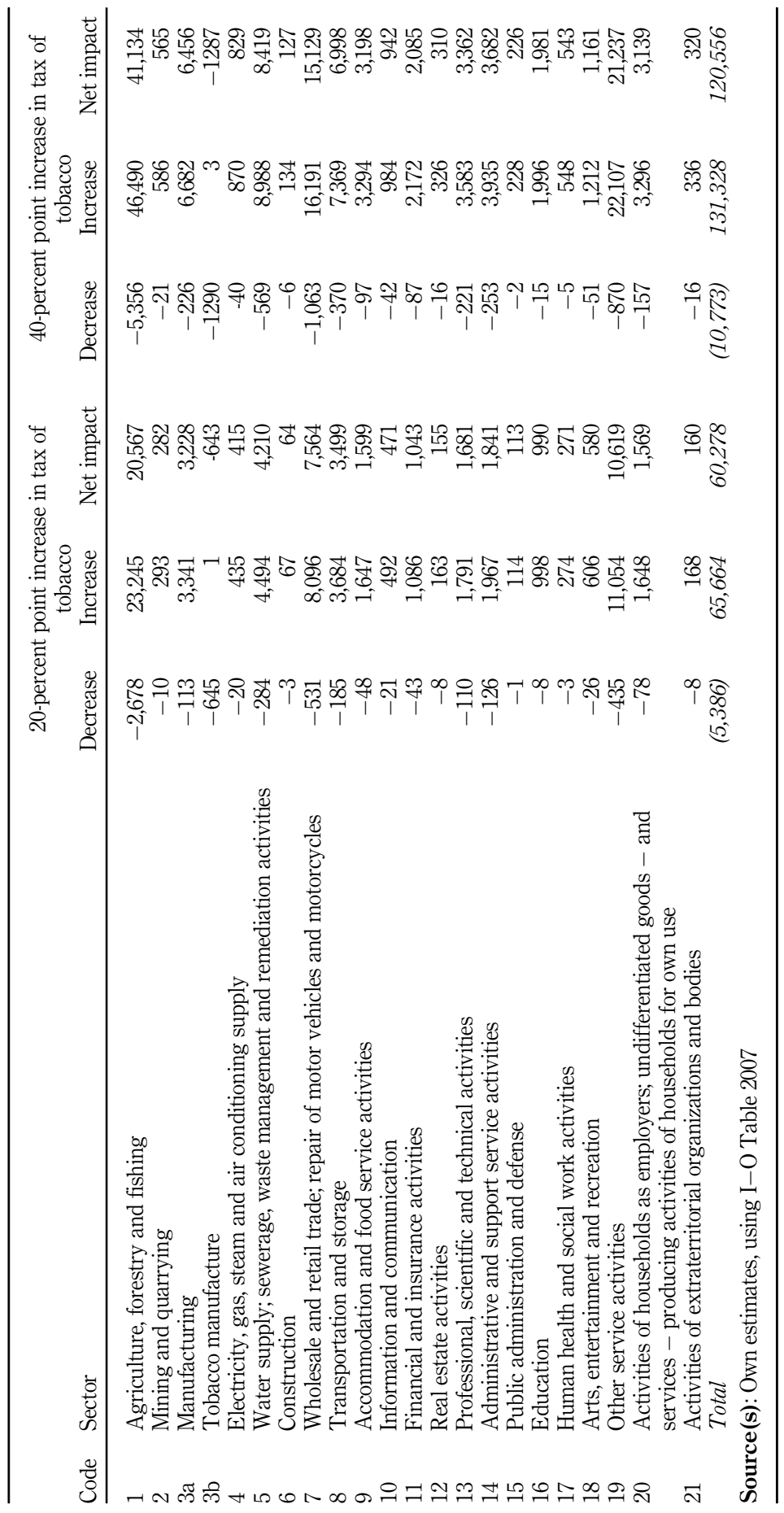

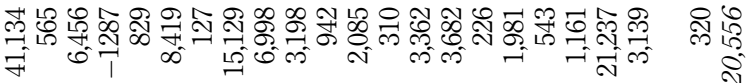

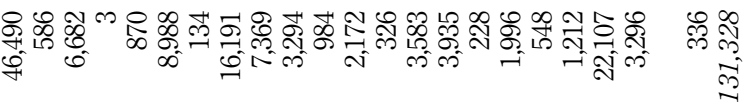

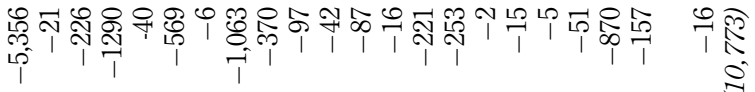

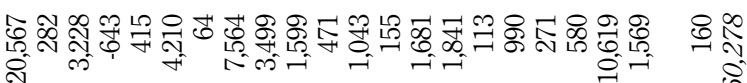

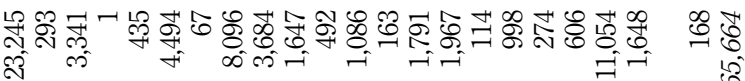

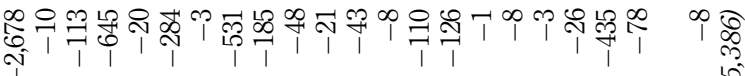


Tobacco control measures would reduce the output in the tobacco industry, but such a reduction would be more than compensated for by increased outputs in other sectors. For the negative impact on employment in the tobacco industry, it would not be a big problem since laborers in the tobacco cultivation and tobacco distribution sectors could be quickly transferred their jobs to other similar sectors. In the tobacco manufacture, however, laborers might find it harder to change their jobs due to required skills, and as such government should have clear plans to help these laborers (such as using a part of increased tax revenue to provide vocational training for them).

Overall, it could be concluded that the impacts of the proposed tobacco control plans in Vietnam on the national output and employment would be positive, and therefore government should increase tax on cigarette and implement other tobacco control policies to prevent smoking and reduce harmless of using tobacco products.

Although this study could add more evidence on tobacco control policies, it could not avoid some limitations. First, the I-O analysis method implicitly assumed the constant return to scale technology, which was not really applicable to all sectors in the economy. Second, assuming that there would be no changes in the government expenditure was quite heroic since government expenditure might be increased along with higher tax collection from increased excise tax on tobacco products. Third, assuming immediate movements of laborers from the tobacco industry to other industries under tobacco control policies was also strong since there would be transitional periods for laborers to seek for jobs.

\section{Notes}

1. Import tax: for cigarettes and cigars: the tax rate is $150 \%$ for all kinds of finished cigarettes (cigars, cigarettes, beedies, cigarettes or cigars made from tobacco-substitutable materials); and for tobacco materials: the tax rate is $30 \%$ (with tobacco stem, the rate is $15 \%$ ). Special consumption tax: (i) cigars: $65 \%$ (in effect since 2005); (ii) cigarettes: $55 \%$ in $2006-2007$ and $65 \%$ since 2008 . Value-added tax: $10 \%$

2. See the last section of this study to present its limitations

3. Note that, using Walbeeck (2010), the impact of demographic changes has been integrated in estimating the impact of higher tax on tobacco on smoking rate

\section{References}

Ahsan, A. and Wiyono, I.N. (2007), Analysis of Higher Tobacco Prices on Employment in Indonesia, Southeast Asia Tobacco Control Alliance (SEATCA), Jakarta.

Barber, S., Adioetomo, S.M., Ahsan, A. and Setyonaluri, D. (2008), Tobacco Economics in Indonesia, International Union Against Tuberculosis and Lung Disease, Paris.

Barkat, A., Chowdhury, A.U., Nargis, N., Rahman, M., Kumar, P.K.A., Bashir, S. and Chaloupka, F.J. (2012), "The economics of tobacco and tobacco taxation in Bangladesh", International Union Against Tuberculosis and Lung Disease, Paris, available at: https://www.tobaccofreekids.org/assets/global/ pdfs/en/Bangladesh_tobacco_taxes_report.pdf (accessed 23 March 2019).

General Statistics Office (GSO) (2010), The Input-Output Table Vietnam 2007, Statistical Publishing House, Hanoi.

Guindon, G.E., Nguyen, T.T.H., Hoang, V.K., McGirr, E., Dang, V.T. and Nguyen, T.L. (2010), Tobacco Taxation in Vietnam, International Union Against Tuberculosis and Lung Disease, Paris.

Higashi, H., Khuong, T.A., Ngo, A.D. and Hill, P.S. (2011), "Substance abuse treatment", Prevention, and Policy, Vol. 6 No. 24, available at: http:/www.substanceabusepolicy.com/content/6/1/24.

Hu, T.W. and Mao, Z. (2002), "Effects of cigarette tax on cigarette consumption and the Chinese economy", Tobacco Control, Vol. 11, pp. 105-108.

Hu, T.W., Mao, Z., Shi, Z.J. and Chen, W. (2008), Tobacco Taxation and its Potential Impact in China, International Union Against Tuberculosis and Lung Disease, Paris. 
JED

22,1

182

John, R.M., Rao, R.K., Rao, M.G., Moore, J., Deshpande, R.S., Sengupta, J., Selvaraj, S., Chaloupka, F.J. and Jha, P. (2010), The Economics of Tobacco and Tobacco Taxation in India, International Union Against Tuberculosis and Lung Disease, Paris.

Levy, D.T., Bales, S., Lam, N.T. and Nikolayev, L. (2006), "The role of public policies in reducing tobacco: policy simulation model”, Social Science and Medicine, Vol. 62, pp. 1819-1830.

Luong, N.K. (2014), "Roadmap for raising special consumption tax on tobacco" (in Vietnamese), Paper presented at the Joint Seminar on Special Consumption Tax by Government Office, Ministry of Finance, and Vietnam Chamber of Commerce and Industry in Vinh Phuc province on 19 May 2014.

Marks, S. (2003), "Cigarette excise taxation in Indonesia: an economic analysis”, Paper prepared for BAPPENAS by Partnership for Economic Growth (PEG) Project.

Mathers, C.D. and Loncar, D. (2006), "Projection of global mortality and burden of disease from 2002 to 2003”, PLoS Medicine, Vol. 3 No. 11, p. e442.

Ministry of Industry and Trade, Vietnam (MOIT) (2012), Project on the Development of Tobacco Products and Materials with a Vision to 2020, (in Vietnamese). MOIT, Hanoi.

Ministry of Finance, Vietnam (MOF) (2013), Report on Purchasing Power and Impacts of Tax Increases, (in Vietnamese, unpublished monograph), MOF, Hanoi.

Ministry of Health, Vietnam (MOH), Hanoi Medical University (HMU), General Statistics Office Vietnam (GSO) and World Health Organization (WHO) (2010), Global Adult Tobacco Survey (GATS) Viet Nam 2010, MOH, HMU, GSO and WHO, Hanoi.

Nguyen, T.T.H., Hoang, V.K. and Hoang, A.T. (2008), "Economic impact of tobacco taxation in Vietnam", unpublished research report, Southeast Asia Tobacco Control Alliance (SEATCA), Bangkok.

Vinataba (2014), "Is this the time to change jobs for tobacco tree growing laborers?", (in Vietnamese), available at: $\mathrm{http} / / \mathrm{www}$. vinataba.com.vn/?module $=$ viewnews\&id $=463$ (accessed 20 October 2018).

VTA (Vietnam Tobacco Association) (2013), Annual Report 2012, (in Vietnamese), VTA, Hanoi.

Walbeeck, C.V. (2010), "A simulation model to predict the fiscal and public health impact of a change in cigarette excise taxes", Tobacco Control, Vol. 19, pp. 31-36.

\begin{abstract}
About the authors
Dr Hien Thu Thi Nguyen is a Senior Lecturer at the Department of Economics, Thuong Mai University. She has various years of experiences working in economics of tobacco control. In particular, in recent five years, she has worked intensively with a number of organizations and research institutions (such as Health Bridge, University of Illinois at Chicago and World Bank) in producing evidence-based economic studies on tobacco in Vietnam. Her studies were published in working papers and journal articles (such as BMJ Open). Hien Thu Thi Nguyen is the corresponding author and can be contacted at: chthuhien@ tmu.edu.vn

Dr Long Thanh Giang is working as an Associate Professor at National Economics University (Hanoi), and as a research fellow at IPAG Business School (Paris). He has extensive experiences in public policy studies, especially in health economics. Prof. Long has worked as consultant for various organizations (such as Asian Development Bank, Health Bridge, ILO, World Bank and World Health Organization), and his research studies were published in a number of journals (such as Social Science and Medicine, Development and Change and Asian Economic Journal).

MSc Toan Ngoc Pham is working for Institute of Labour Science and Social Affairs (ILSSA) at Ministry of Labour, War Invalids and Social Affairs (MOLISA). He has involved in various policy research projects related to labor, income and tax issues. His research results were published in different journals (such as Journal of Economics and Development, BMJ Open).
\end{abstract}

For instructions on how to order reprints of this article, please visit our website:

www.emeraldgrouppublishing.com/licensing/reprints.htm

Or contact us for further details: permissions@emeraldinsight.com 